\title{
Potential Stress due to Environmental Conditions in the 2004 Summer Olympic Games
}

\author{
George P. Nassis and Nickos D. Geladas \\ Department of Sport Medicine and Biology of Physical Activity, \\ Faculty of Physical Education and Sport Science, University of Athens, Greece \\ E-mail: ngeladas@cc.uoa.gr and gnassis@cc.uoa.gr
}

(received on September 30, 2002, accepted on October 29, 2002)

\begin{abstract}
The aim of this study was to analyze the prevailing environmental conditions during August in the past 10-30 years in the city of Athens where the 2004 Olympic Games are going to be held. A secondary aim was to relate these conditions to performance, based on the existing literature. Ozone, carbon monoxide (CO), nitrogen dioxide $\left(\mathrm{NO}_{2}\right)$ and sulphur dioxide $\left(\mathrm{SO}_{2}\right)$ concentrations, hourly and daily recorded, in August over the past 10 years were collected from the Greek Ministry of Environment. Ambient dry temperature and relative humidity, every three hours and daily recorded, in August over the past 30 years were collected from the National Meteorological Bureau. $\mathrm{CO}, \mathrm{NO}_{2}$ and $\mathrm{SO}_{2}$ levels were below the World Health Organization (WHO) guideline values and the national alarm levels. However, 8-hours $\mathrm{O}_{3}$ concentration was higher than the WHO guideline values at certain cases. Ambient temperature ranged between 19.7 and $34.8^{\circ} \mathrm{C}$ in the site close to the Olympic sports complex whereas relative humidity was 25 to $60 \%$. In conclusion, a high $\mathrm{O}_{3}$ concentration could be a threat to endurance performance in the 2004 summer Olympic Games. The negative impact of $\mathrm{O}_{3}$ inhalation on health and performance could be exaggerated in the presence of a high ambient temperature. Proper acclimation strategies could minimize the adverse effects of heat on human body function. Acclimation could also alleviate the respiratory symptoms of $\mathrm{O}_{3}$ inhalation, at least in some individuals.
\end{abstract}

Key words: Environmental pollution-heat stress-athletic performance-olympic games

\section{Introduction}

Air pollution, high ambient temperature and relative humidity may affect athletic performance in a negative manner (Gallow and Maughan, 1997; Raven, 1987). The major air pollutants are carbon monoxide $(\mathrm{CO})$, ozon $\left(\mathrm{O}_{3}\right)$, nitrogen dioxide $\left(\mathrm{NO}_{2}\right)$ and sulphur dioxide $\left(\mathrm{SO}_{2}\right)$. Carbon monoxide is a gas that is readily absorbed from inspired air and combines with haemoglobin to interfere with tissue oxygenation. Maximum oxygen uptake $\left(\mathrm{V}^{2}{ }_{2 \max }\right)$ is reduced linearly with increasing blood levels of carboxyhaemoglobin $(\mathrm{COHb})$. The decline in $\dot{\mathrm{V}}_{2 \max }$, however, is statistically significant when $\mathrm{COHb}$ exceeds $4.3 \%$ (Horvath et al., 1975). In addition, levels of $\mathrm{COHb}$ higher than $2.7 \%$ result in reduced exercise time (Raven et al., 1974).

Ozone is formed by a reaction cycle involving nitrogen monoxide, nitrogen dioxide, oxygen, hydrocarbons and energy from ultraviolet radiation. One hour exposure to $\mathrm{O}_{3}$ levels of 400 to $600 \mu \mathrm{g} / \mathrm{m}^{3}(0.20$ to $0.30 \mathrm{ppm}$ ) results in a significant decline in forced vital capacity (FVC), forced expiratory volume in one second $\left(\mathrm{FEV}_{1}\right)$ and mean forced expiratory flow between 25 and $75 \%$ of FVC at rest (Folinsbee et al., 1977). During longer exposure (6.5 hours), the adverse effect of ozone on health is significant at 160 $\mu \mathrm{g} / \mathrm{m}^{3}(0.08 \mathrm{ppm})$ in healthy adults [World Health Organization (WHO), 2000]. In one hour exercise, performance time was reduced at $\mathrm{O}_{3}$ levels higher than $240 \mu \mathrm{g} / \mathrm{m}^{3}$ despite the fact that this reduction became statistically significant at ozone concentration of $480 \mu \mathrm{g} / \mathrm{m}^{3}$ in another study (Schelegle and Adams, 1986). The effect of $\mathrm{O}_{3}$ on respiratory function and exercise performance is likely to be more severe when high $\mathrm{O}_{3}$ levels are combined with elevated ambient temperature (i.e. higher than $30^{\circ} \mathrm{C}$; Folinsbee et al., 1977; Gibbons and Adams, 1984).

Available evidence indicates that acute exposure to $\mathrm{NO}_{2}$ concentration of less than $1880 \mu \mathrm{g} / \mathrm{m}^{3}$ rarely produces observable effects (WHO, 2000). Sulphur dioxide is generally regarded as an upper airway and bronchial irritant. People with asthma are the most 
sensitive group to $\mathrm{SO}_{2}$ exposure (WHO, 2000).

The 2004 Olympic Games are going to be held in the city of Athens, Greece, between August 13th and August 29th. It is speculated (Tziortzis, S. et al., 1992) that environmental conditions could pose a stress to human organism and thus could be a threat to athletic performance. Thus, the aim of this study was to analyze the prevailing environmental conditions during August in the past 10-30 years in the city of Athens and relate them to performance, based on the existing evidence in the literature.

\section{Materials and methods}

Ozone, $\mathrm{CO}, \mathrm{NO}_{2}$ and $\mathrm{SO}_{2}$ concentrations, hourly and daily recorded, in August over the past 10 years were collected from the Department of Air Quality, a pollution monitoring division of the Greek Ministry of Environment, Physical Planning and Public Works. The results from three sites are presented in this paper (Maroussi, Liosia and N. Smirni). Maroussi station is about $1 \mathrm{~km}$ from the Olympic sports complex which includes the main stadium, the velodrome, the tennis courts, the swimming pool and the facilities for the basketball and soccer tournaments. The station at Liosia is about $2 \mathrm{~km}$ from the athletes' Olympic village whereas the third station (N. Smirni) is about $5 \mathrm{~km}$ from the Saint Kosmas and Elliniko sports complex. In that area, which is by the sea, the following events are going to be held: triathlon, baseball, hockey, canoe-cayak and sailing. The methodology for the determination of the concentration of each of the above pollutants is presented in the technical report published by the Ministry of Environment (2001).

Ambient dry temperature and relative humidity, every three hours and daily recorded, in August over the past 30 years were collected from the Greek National Meteorological Bureau. Data from two stations are reported: one which is about $2 \mathrm{~km}$ north west of the Olympic Sports complex (Philadelphia) and the other one about $1 \mathrm{~km}$ west of the Saint Kosmas sports complex (Elliniko).

\section{Results}

The highest values for the major air pollutants recorded in August over the past 10 years at the three sites of Athens in comparison with the WHO guideline values and the National alarm levels are presented in Table 1.

Carbon monoxide, $\mathrm{NO}_{2}$ and $\mathrm{SO}_{2}$ concentrations were far below the WHO guideline values and the national alarm levels. In addition, there was a clear tendency for lower concentration for all air pollutants in all three sites over the last years. However, 8-hours (between 8 am and 4 pm) $\mathrm{O}_{3}$ concentration was higher than the WHO guideline value $\left(120 \mu \mathrm{g} / \mathrm{m}^{3}\right)$ in the site close to the Olympic sports complex in August $1991\left(136.4 \mu \mathrm{g} / \mathrm{m}^{3}\right), 1992\left(145.2 \mu \mathrm{g} / \mathrm{m}^{3}\right), 1994$ $\left(124.1 \mu \mathrm{g} / \mathrm{m}^{3}\right), 1996\left(124.6 \mu \mathrm{g} / \mathrm{m}^{3}\right)$ and $1998(127.4$ $\mu \mathrm{g} / \mathrm{m}^{3}$ ) (Fig. 1 and Table 1). It should be noted, however, that $\mathrm{O}_{3}$ concentration presented a tendency for lower values at the region of Maroussi in the year 2000 (Fig. 1). The monthly mean concentration for the air pollutants studied for the year 2000 in the site close to the Olympic sports complex is presented in Fig. 2.

Mean 24-hours ozone concentration for the years 1990-2000 was $91.8,95.1$ and $85 \mu \mathrm{g} / \mathrm{m}^{3}$ for the site close to the Olympic sports complex, the athletes village and the S. Kosmas center, respectively. The 24-hours mean ambient dry temperature and relative humidity in August for the past 30 years are shown in Table 2. Ambient temperature ranged between 19.7 and $34.8^{\circ} \mathrm{C}$ in Philadelphia and between 21.0 to $33.5^{\circ} \mathrm{C}$ in Elliniko.

Finally, every 3 hour variation in temperature and relative humidity for the site close to the Olympic stadium complex (Philadelphia) is presented in Fig. 3 and Fig. 4, respectively.

\section{Discussion}

This analysis showed that although $\mathrm{CO}, \mathrm{NO}_{2}$ and $\mathrm{SO}_{2}$ concentrations were far below the WHO guideline values in August over the past 10 years, $\mathrm{O}_{3}$ concentration exceeded these levels at certain cases. It should be noted that air pollutants concentration presented a tendency for lower values over the last years. It is speculated, however, that a high ozone concentration might be a threat to athletic performance in the 2004 Athens Olympic Games. The effect of $\mathrm{O}_{3}$ inhalation on respiratory system function could be exaggerated in the presence of an elevated ambient temperature. In addition, the high ambient temperature per se could be detrimental to performance especially in the long lasting events in the Athens Olympic games.

As Fig. 2 shows, $\mathrm{O}_{3}$ levels were higher in the summer than the winter. A diurnal pattern was also observed, peaking around midday well after the morning rush hour and when solar radiation is at its highest (Fig. 1). Eight-hours (from 8 am to $4 \mathrm{pm}$ ) ozone concentration for the site close to the Olympic Stadium was higher than $120 \mu \mathrm{g} / \mathrm{m}^{3}$, which is the WHO guideline value, in 1991, 1992, 1994, 1996 and 1998 (Fig. 1). It must be noted at this point that although the WHO guidelines for air quality values are health based levels, they are not standards per se. Air quality standards are quality guidelines decided by governments, for which additional factors may be considered. These factors include the particular environ- 
Table 1. The highest mean values for the major air pollutants recorded in the past 10 years in the three sites of Athens where the majority of athletic events in the 2004 summer Olympic Games are going to take place (Maroussi, Liosia and N. Smirni). The WHO guideline values and the national alarm level values are also included in the final two columns.

\begin{tabular}{|c|c|c|c|c|c|c|}
\hline Pollutant & & $\begin{array}{c}\text { Highest } \\
\text { value } \\
\left(\mu \mathrm{g} / \mathrm{m}^{3}\right)\end{array}$ & & $\begin{array}{c}\text { Averaging } \\
\text { time }\end{array}$ & $\begin{array}{c}\text { WHO } \\
\text { guideline } \\
\text { value } \\
\left(\mu \mathrm{g} / \mathrm{m}^{3}\right)\end{array}$ & $\begin{array}{c}\text { National } \\
\text { alarm } \\
\text { level } \\
\left(\mu \mathrm{g} / \mathrm{m}^{3}\right)\end{array}$ \\
\hline Site & Maroussi & Liosia & N. Smirni & & & \\
\hline CO & $\begin{array}{c}11800 \text { at } \\
9.00 \mathrm{am} \text { in } \\
1992\end{array}$ & NA & $\begin{array}{c}6500 \text { at } \\
8.00 \text { am in } \\
1994\end{array}$ & $1 \mathrm{hr}$ & $\begin{array}{c}30000 \\
\text { in } 1 \mathrm{hr} \\
10000 \\
\text { in } 8 \mathrm{hrs}\end{array}$ & $\begin{array}{c}20000 \\
\text { in } 8 \mathrm{hrs}\end{array}$ \\
\hline $\mathbf{O}_{3}$ & $\begin{array}{l}159.9 \text { at } \\
1.00 \mathrm{pm} \\
\text { in } 1992\end{array}$ & $\begin{array}{l}157.2 \text { at } \\
2.00 \mathrm{pm} \\
\text { in } 1993\end{array}$ & $\begin{array}{l}151.5 \text { at } \\
4.00 \mathrm{pm} \\
\text { in } 1992\end{array}$ & $1 \mathrm{hr}$ & $\begin{array}{c}120 \\
\text { in } 8 \mathrm{hrs}\end{array}$ & $\begin{array}{c}180 \\
\text { in } 1 \mathrm{hr}\end{array}$ \\
\hline $\mathrm{NO}_{2}$ & $\begin{array}{c}87.5 \text { at } \\
10.00 \text { am } \\
\text { in } 1993\end{array}$ & $\begin{array}{c}63.8 \text { at } \\
9.00 \text { am in } \\
1990\end{array}$ & $\begin{array}{c}89.3 \text { at } \\
9.00 \text { am in } \\
1999\end{array}$ & $1 \mathrm{hr}$ & $\begin{array}{c}200 \\
\text { in } 1 \mathrm{hr}\end{array}$ & $\begin{array}{c}400 \\
\text { in } 1 \mathrm{hr}\end{array}$ \\
\hline $\mathrm{SO}_{2}$ & $\begin{array}{c}18.7 \text { in } \\
1993\end{array}$ & $\begin{array}{c}37.5 \text { in } \\
1990\end{array}$ & $\begin{array}{c}34.4 \text { in } \\
1996\end{array}$ & $24 \mathrm{hrs}$ & $\begin{array}{c}125 \\
\text { in } 24 \mathrm{hrs}\end{array}$ & $\begin{array}{c}250 \\
\text { in } 24 \mathrm{hrs}\end{array}$ \\
\hline
\end{tabular}

Maroussis is about $2 \mathrm{~km}$ from the Olympic sports complex; Liosia is about $2 \mathrm{~km}$ from the athletes' village; N. Smirni is about $5 \mathrm{~km}$ from S. Kosmas and Elliniko sports complex; NA means that data were not available due to technical reasons.

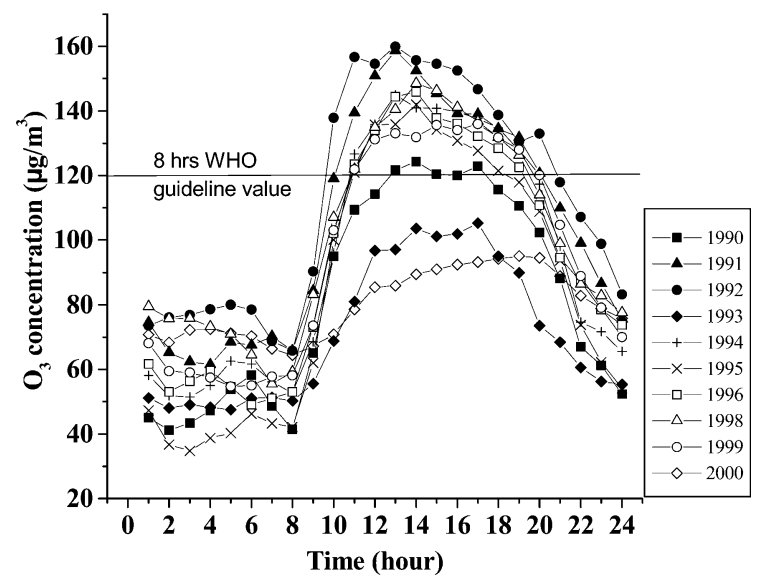

Fig. 1. Mean hourly recorded values for ozone concentration for the site close to the Olympic sports complex (Maroussi). Values are the means for August 1st to August 31 st for the years 1990 to 2000 (values for the year 1997 are missing due to technical problems presented in the station).

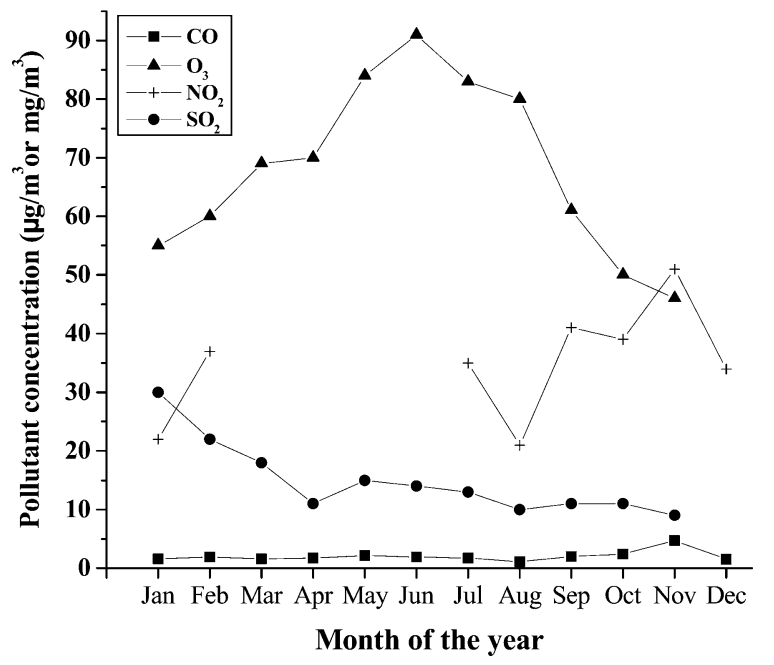

Fig. 2. Mean monthly concentration of air pollutants in the year 2000 for the site close to the Olympic sports complex (Maroussi). Units are $\mathrm{mg} / \mathrm{m}^{3}$ for carbon monoxide and $\mu \mathrm{g} / \mathrm{m}^{3}$ for ozone, nitrogen dioxide and sulphur dioxide. Missing values for $\mathrm{NO}_{2}$ are due to technical problems in the station. 
Table 2. Climatic conditions in two sites of Athens where major athletic events of the 2004 Olympic Games are going to be held (values are $3 \mathrm{hr}$ means \pm SD for August 1st to August 31st for the years 1970-1999).

\begin{tabular}{lcc}
\hline & Philadelphia & Elliniko \\
\hline Mean $\left({ }^{\circ} \mathrm{C}\right)$ & $28.3 \pm 3.8$ & $27.0 \pm 2.9$ \\
Range (min-max) & $19.7-34.8$ & $21.0-33.5$ \\
Maximum $\left({ }^{\circ} \mathrm{C}\right)$ & $33.2 \pm 1.2$ & $31.5 \pm 1.2$ \\
Absolute maximum $\left({ }^{\circ} \mathrm{C}\right)$ & 43.0 & 40.2 \\
Relative Humidity $(\%)$ & $42.1 \pm 11.9$ & $47.8 \pm 8.8$ \\
\hline
\end{tabular}

Philadelphia is about $2 \mathrm{~km} \mathrm{NW}$ of the Olympic sports complex; Elliniko is about $1 \mathrm{~km}$ West of the $\mathrm{S}$. Kosmas sports complex.

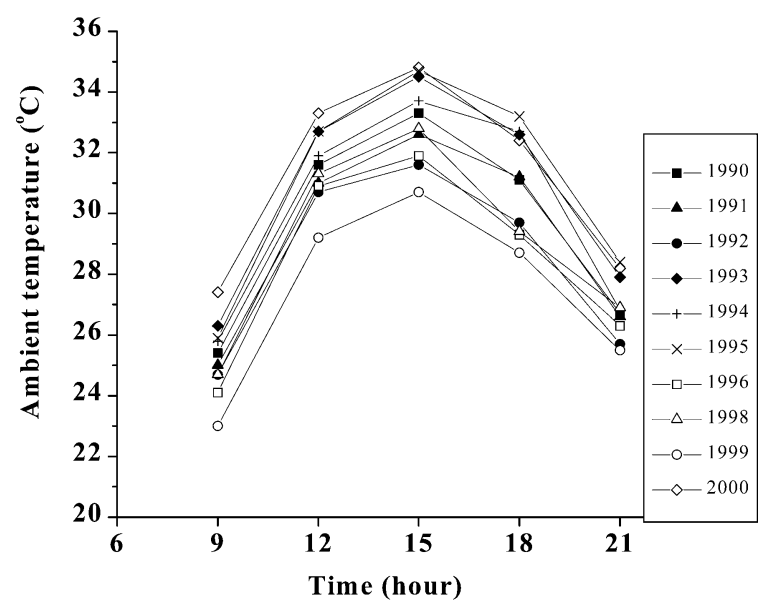

Fig. 3. Mean every 3 hours recorded values for ambient temperature for the site close to the Olympic sports complex (Philadelphia). Values are the means for August 1st to August 31st for the years 1990 to 2000 (values for the year 1997 are missing due to technical problems presented in the station).

mental conditions, the prevailing exposure levels and socio-economic factors (WHO, 2000).

Ozone levels in the particular regions of Athens were similar to those reported for Sydney in September 2000 but much lower that those reported for Atlanta during the 1996 Olympic Games (Table 3). Ozone inhalation has been shown to decrease FVC, $\mathrm{FEV}_{1}$ and total lung capacity (Hazucha et al., 1989). Moreover, $\mathrm{O}_{3}$ inhalation is accompanied by discomfort and symptoms such as chest pain, cough, sore throat etc (Hazucha et al., 1989). Exercise performance decrements have been reported at $\mathrm{O}_{3}$ concentration higher than $400 \mu \mathrm{g} / \mathrm{m}^{3}$ inspired for about an hour (Schelegle and Adams, 1986). It is suggested that $\mathrm{O}_{3}$ inhalation stimulates airway receptors/nerve endings leading to an involuntary inhibition of full inspiration, reduction of total lung capacity and vital capacity, a concomitant decrease in maximal expiratory flow rates and possibly an increased respiratory fre-

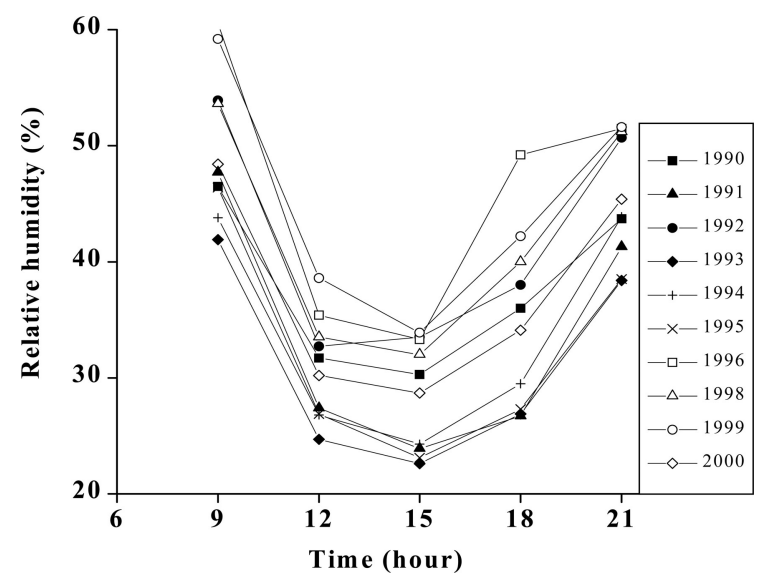

Fig. 4. Mean every 3 hours recorded values for relative humidity for the site close to the Olympic sports complex (Philadelphia). Values are the means for August 1st to August 31st for the years 1990 to 2000 (values for the year 1997 are missing due to technical problems presented in the station).

quency during exercise (Hazucha et al., 1989).

However, the mechanism of reduced exercise performance with $\mathrm{O}_{3}$ inhalation is unknown. Bates (1980) has suggested several mechanisms, which may lead to endurance performance decrements during ozone exposure. These include reduced alveolar ventilation-perfusion ratio, decreased oxygen saturation in arterial blood and an increased energy requirement of respiratory muscles. However, no significant difference in heart rate, oxygen uptake, ventilation, respiratory rate and tidal volume between the ozone exposure and the control condition was observed in most studies (Adams and Schelegle, 1983; Gibbons and Adams, 1984; Schelegle and Adams, 1986). Therefore, it is unlikely that any of the proposed mechanisms were influential to exercise performance. It seems that subjects' unwillingness to continue exercise is possibly due to the respiratory symptoms (Adams and Schelegle, 1983; Folinsbee et al., 1977).

Although these symptoms are exaggerated at higher $\mathrm{O}_{3}$ levels than those reported for the city of Athens in the present paper, the following points should be taken into consideration before reaching any conclusion: i) $\mathrm{O}_{3}$ inhalation negative effects may be increased in the presence of an elevated ambient temperature (Gibbons and Adams, 1984), ii) some individuals are more susceptible to a certain $\mathrm{O}_{3}$ level than others (Adams and Schelegle, 1983), iii) women generally present greater decrements in lung function for a given effective $\mathrm{O}_{3}$ level than males (Lauritzen and Adams, 1985), and iv) endurance athletes may be more susceptible to the effects of a given $\mathrm{O}_{3}$ concentration than normal individuals as a result of sustained high ventilation (Adams and Schelegle, 1983). With respect to the second (ii) point, in the study of 
Table 3. Air quality and meteorological data during the 2000 Sydney and 1996 Atlanta Olympic Games.

\begin{tabular}{|c|c|c|}
\hline Parameter & $\begin{array}{c}\text { Sydney } \\
\text { (September 2000) }\end{array}$ & $\begin{array}{c}\text { Atlanta } \\
(19 / 7-4 / 8 / 1996)\end{array}$ \\
\hline $\mathrm{CO} \mu \mathrm{g} / \mathrm{m}^{3}(\mathrm{ppm})$ & $7.78(0.007)^{\mathrm{a}}$ & $1500(1.35)^{b}$ \\
\hline $\mathrm{O}_{3} \mu \mathrm{g} / \mathrm{m}^{3}(\mathrm{ppm})$ & $72(0.036)^{\mathrm{c}}$ & $120(0.06)^{\mathrm{c}}$ \\
\hline $\mathrm{NO}_{2} \mu \mathrm{g} / \mathrm{m}^{3}(\mathrm{ppm})$ & $50.8(0.027)^{c}$ & $56.4(0.03)^{\mathrm{c}}$ \\
\hline $\mathrm{SO}_{2} \mu \mathrm{g} / \mathrm{m}^{3}(\mathrm{ppm})$ & $2.57(0.0009)^{\mathrm{a}}$ & $8.57(0.003)^{\mathrm{a}}$ \\
\hline Temperature range $\left({ }^{\circ} \mathrm{C}\right)$ & $14.4-33.8^{\mathrm{d}}$ & $22.8-36.1^{\mathrm{d}}$ \\
\hline Mean temperature $\left({ }^{\circ} \mathrm{C}\right)$ & $19.4^{\mathrm{d}}$ & $29.6^{d}$ \\
\hline Humidity (\%) & $18-90^{d}$ & $45-93^{d}$ \\
\hline
\end{tabular}

Adams and Schelegle (1983) the work loads were set to elicit a mean ventilation rate of $801 / \mathrm{min}$ for all individuals. Despite that, a wide range of $\mathrm{O}_{3}$ toxicity was observed which was evidenced by greater pulmonary function impairment in the most sensitive subjects (Adams and Schelegle, 1983). With regard to the latter (iv) point, it is suggested that the increased ventilation rate of athletes will increase the quantity of pollutants inhaled and will also carry pollutants deeper into the respiratory tract (Carlisle and Sharp, 2001). From the above discussion, it appears that $\mathrm{O}_{3}$ levels could have a detrimental effect to performance in the upcoming summer Olympic Games.

Regarding the other air pollutants presented in this paper, it must be noted that all of them were below the WHO guideline values and the National alarm levels over the past 10 years in the city of Athens (Table 1). The highest mean $\mathrm{CO}$ level was around $12000 \mu \mathrm{g} / \mathrm{m}^{3}$ for the site close to the Olympic stadium. The mean CO concentration for this site and the one close to the S. Kosmas sport complex in 2000 were higher compared with the value reported for Sydney in September 2000 (1100 and 700 vs 7.78 $\mu \mathrm{g} / \mathrm{m}^{3}$, respectively) but lower than that reported for Atlanta during the 1996 Olympic Games (1500 $\left.\mu \mathrm{g} / \mathrm{m}^{3}\right)$. Literature review shows that to achieve a $\mathrm{COHb}$ level higher than $2.7 \%$, at which level exercise performance is significantly reduced, athletes should be exposed to a CO concentration greater than 70000 $\mu \mathrm{g} / \mathrm{m}^{3}$ (60 ppm) for 1 hour or $23000 \mu \mathrm{g} / \mathrm{m}^{3}$ (20 ppm) for 8 hours (Carlisle and Sharp, 2001). These levels were not reached in the three sites of Athens in $\mathrm{Au}$ gust over the last 10 years. Regarding the $\mathrm{NO}_{2}$ levels, it seems that $\mathrm{NO}_{2}$ inhalation has a negative effect on both health and performance at levels around 565 $\mu \mathrm{g} / \mathrm{m}^{3}$ in asthmatic individuals (WHO, 2000). Very few experiments have been conducted on the effect of $\mathrm{SO}_{2}$ on exercise performance (Linn et al., 1983). Based on the available evidence, it is suggested that exercise performance is affected only at high $\mathrm{SO}_{2}$ concentrations (i.e. $2857 \mu \mathrm{g} / \mathrm{m}^{3}$ or $1 \mathrm{ppm}$; Raven, 1987). Acute responses occur within the first few minutes of inhalation and include reductions in $\mathrm{FEV}_{1}$, increases in specific airway resistance and symptoms such as shortness of breath (WHO, 2000). As Table 1 shows the highest recorded values for both $\mathrm{NO}_{2}$ and $\mathrm{SO}_{2}$ at the three sites of Athens were far below these threshold values. Therefore, it seems that $\mathrm{SO}_{2}$ and $\mathrm{NO}_{2}$ levels would not pose a threat to performance in the Athens 2004 summer Olympic Games.

Ambient temperature is generally high between 9 am and $9 \mathrm{pm}$ in the city of Athens in August. Indeed, ambient temperature ranged from 19.7 to $34.8^{\circ} \mathrm{C}$ whereas maximum values of 43.0 and $40.2^{\circ} \mathrm{C}$ have been recorded in Philadelphia and Elliniko, respectively, in the year 1999 (Table 2). Relative humidity which could affect athletic performance was relatively low (between 25 and $60 \%$ for the time period 9 am to 9 pm; Fig. 3). During the 2000 Sydney Olympic Games, ambient temperature ranged from 14.4 to $33.8^{\circ} \mathrm{C}$, whereas humidity from 18 to $90 \%$ in the period 8 am and $9 \mathrm{pm}$. In Atlanta, the respective values were from 22.8 to $36.1^{\circ} \mathrm{C}$ and from 45 to $93 \%$ (Table 3). The effect of high temperature on exercise performance was examined by Gallow and Maughan (1997). Eight subjects exercised at $70 \% \mathrm{VO}_{2 \max }$ at four different ambient conditions with dry tempera- 
Table 4. Sign and symptoms of exposure to certain pollutant. Precautionary steps to minimize these symptoms.

\begin{tabular}{|c|c|c|c|}
\hline Pollutant & Sign and symptoms & effect level & Precautionary steps \\
\hline CO & - Hypoxic effects on various organs & n.a. & $\begin{array}{l}\text { - Avoid exercise by a busy road side } \\
\text { - Avoid smoky environments and car } \\
\text { journeys in heavy traffic before } \\
\text { competition }\end{array}$ \\
\hline \multirow[t]{3}{*}{$\mathbf{O}_{3}$} & \multirow[t]{3}{*}{$\begin{array}{l}\text { - Nose and throat irritation } \\
\text { - Coughing, wheezing } \\
\text { - Shortness of breath } \\
\text { - Nausea }\end{array}$} & \multirow[t]{3}{*}{ n.a. } & $\begin{array}{l}\text { - Check the pollution forecast and take } \\
\text { heed of any warnings } \\
\text { - Exercise in the early morning or the } \\
\text { late evening }\end{array}$ \\
\hline & & & $\begin{array}{l}\text { - Avoid outdoor exercise in peak } \\
\text { pollution episodes }\end{array}$ \\
\hline & & & $\begin{array}{l}\text { - Follow a certain diet including } \\
\text { antioxidants, vitamin } \mathrm{E} \\
\text { - Adapt to heat and high } \mathrm{O}_{3} \text { levels }\end{array}$ \\
\hline $\mathrm{NO}_{2}$ & $\begin{array}{l}\text { - Changes in lung function } \\
\text { - Asthmatics are the most sensitive group }\end{array}$ & $365-565 \mu \mathrm{g} / \mathrm{m}^{3}$ & - Avoid exercise by a busy road side \\
\hline $\mathrm{SO}_{2}$ & $\begin{array}{l}\text { - Wheezing and shortness of breath } \\
\text { - Acute symptoms within the first few } \\
\text { minutes } \\
\text { - Asthmatics are the most sensitive group }\end{array}$ & $\begin{array}{l}1000 \mu \mathrm{g} / \mathrm{m}^{3} \text { in } 10 \mathrm{~min} \\
250 \mu \mathrm{g} / \mathrm{m}^{3} \text { in } 24 \mathrm{hrs}\end{array}$ & $\begin{array}{l}\text { - Check the pollution forecast and take } \\
\text { heed of any warnings } \\
\text { - Avoid exercise by a busy road side } \\
\text { - Asthmatic athletes may need } \\
\text { prophylactic medication }\end{array}$ \\
\hline
\end{tabular}

n.a. not applicable.

ture of $4,10,21$ and $40^{\circ} \mathrm{C}$. Their results showed a $37 \%$ lower performance time at $30^{\circ} \mathrm{C}$ compared with $21^{\circ} \mathrm{C}$ (55 vs $81 \mathrm{~min}$, respectively; Gallow and Maughan, 1997). Performance reduction during prolonged exercise in the heat is attributed to dehydration and hyperthermia which both affect the cardiovascular and thermoregulatory system function (Gonzalez-Alonso et al., 1997; Nassis and Geladas, 2002). Under such conditions stroke volume, arterial and pulmonary pressures, cardiac output and blood flow in the working muscles progressively decline (González-Alonso et al., 1998). Based on the above discussion, it seems that heat stress could threaten performance in the 2004 Olympic Games especially in the long lasting events.

To alleviate the negative effect of heat on exercise performance certain acclimation strategies have been suggested (Nielsen et al., 1993; Wenger, 1988). Generally, it seems that a period of 10-14 days is needed for adaptations in the heat to occur (Nielsen et al., 1993). Certain acclimation strategies have also been proposed for the decline of symptoms due to $\mathrm{O}_{3}$ inhalation. Hackney et al. (1977) had 6 subjects exposed in an environmental chamber to $1000 \mu \mathrm{g} / \mathrm{m}^{3}$ (0.50 ppm) 2 hours per day for 4 successive days. One subject did not adapt while five of them presented an adaptation. A failure of adaptation for 3 of 11 subjects who followed exactly the same protocol was reported in another study (Linn et al., 1982). It seems therefore that short term exposure at high $\mathrm{O}_{3}$ levels may reduce the respiratory symptoms in some but not all individuals.

Diet may also be important in reducing the symp- toms of $\mathrm{O}_{3}$ inhalation. There is some evidence that vitamin $\mathrm{E}$ intake may prevent some negative effects of $\mathrm{O}_{3}$ exposure in animals but such evidence is lacking in humans (Pierson et al., 1986). It is also suggested that antioxidant supplementation may reduce the detrimental effects of ozone in humans (Carlisle and Sharp, 2001). Advice to those exercising is to stay away of busy roads since there is an exponential decline in many pollutants concentration with increasing distance from the busy roads (Table 4). In addition, those who plan exercising should check the pollution forecast and schedule training early in the morning or late in the afternoon when air pollution episodes are lower. Air pollution and especially high $\mathrm{NO}_{2}$ and $\mathrm{O}_{3}$ levels can make asthma worse (WHO, 2000). Athletes with asthma should stay indoors and avoid heavy exercise, if possible, on high pollution days. In other case, they should consult their doctors for increasing their medication.

In conclusion, the analysis of this study showed that a high $\mathrm{O}_{3}$ concentration could be a threat to performance in the 2004 summer Olympic Games. The negative impact of $\mathrm{O}_{3}$ inhalation on health and performance could be exaggerated in the presence of a high ambient temperature. Proper acclimation strategies could minimize the adverse effects of heat on cardiovascular and thermoregulatory system. Acclimation could also alleviate the respiratory symptoms due to $\mathrm{O}_{3}$ inhalation at least in some individuals.

\section{Acknowledgments}

The technical assistance of the Ministry of Environment, Physical Planning and Public Works as well 
as that of the National Meteorological Bureau is greatly appreciated. Views in this manuscript are those of the authors and should not be construed as an official position, policy or decision of the aforementioned agencies.

\section{References}

Adams, W. C. and Schelegle, E. S. (1983) 'Ozone and high ventilation effects on pulmonary function and endurance performance', Journal of Applied Physiology, 55, 805812.

Bates, D. V. 1980. Effects of irritant gases on maximal exercise performance, in: Exercise Bioenergetics and Gas Exchange, Cerretelli, P. and Whipp, B. J. (Eds), Elsevier North Holland Biomedical Press, Amsterdam. p. 337344.

Bureau of Meteorology. http://www.bom.gov.au/olympic/

Carlisle, A. J. and Sharp, N. C. C. (2001) 'Exercise and outdoor ambient air pollution', British Journal of Sport Medicine, 35, 214-222.

Folinsbee, L. J., Silverman, F. and Shephard, R. J. (1977) 'Decrease of maximum work performance following ozone exposure', Journal of Applied Physiology, 42, 531-536.

Friedman, M. S., Powell, K. E., Hutwagner, L., Graham, L. M. and Teague. W. G. (2001). 'Impact of changes in trasportation and commuting behaviors during the 1996 summer Olympic Games in Atlanta on air quality and childhood asthma', Journal of the American Medical Association, 285, 897-905.

Galloway, S. D. R. and Maughan, R. J. (1997) 'Effects of ambient temperature on the capacity to perform prolonged cycle exercise in man', Medicine and Science in Sports and Exercise, 29, 1240-1249.

Georgia Department of Natural Resources, Environment Protection Division, Air Protection Branch. http://www. air.dnr.state.us/

Gibbons, S. I. and Adams, W. C. (1984) 'Combined effects of ozone exposure and ambient heat on exercising females', Journal of Applied Physiology, 57, 450-456.

González-Alonso, J., Mora-Rodriguez, R., Below, P. R. and Coyle E. F. (1997) 'Dehydration markedly impairs cardiovascular function in hyperthermic endurance athletes during exercise', Journal of Applied Physiology, 82: 1229-1236.

González-Alonso, J., Calbet, J. and Nielsen, B. (1998) 'Muscle blood flow is reduced with dehydration during prolonged exercise in humans', Journal of Physiology (London), 513: 895-905.

Hackney, J. D., Linn, W. S., Mohler, J. G. and Collier, C. R. (1977) 'Adaptation to short-term respiratory effects of ozone in men exposed repeatedly', Journal of Applied Physiology, 43, 82-85.

Hazucha, M. J., Bates, D. V. and Bromberg, P. A. (1989) 'Mechanism of action of ozone on the human lung', Journal of Applied Physiology, 67, 1535-1541.

Horvath, S. M., Raven P. B., Dahms, T. E. and Gray, D. J. (1975) 'Maximal aerobic capacity at different levels of carboxyhemoglobin', Journal of Applied Physiology, 38, 300-303.

Lauritzen, S. K. and Adams, W. C. (1985) 'Ozone inhalation effects consequent to continuous exercise in females: comparison to males', Journal of Applied Physiology, 59, 1601-1606.

Linn, W. S., Medway, D. A., Anzar, U. T., Valencia, L. M., Spier, C. E., Tsao, F. S., Fischer, D. A. and Hackney, J. D. (1982) 'Persistence of adaptation to ozone in volunteers exposed repeatedly for six weeks', American Review of Respiratory Diseases, 125, 491-495.

Linn, W. S., Venet, T. G., Shamoo, D. A., Valencia, L. M., Anzar, U. T., Spier, C. E. and Hackney, J. D. (1983) 'Respiratory effects of sulphur dioxide in heavily exercising asthmatics', American Review of Respiratory Diseases, 127, 278-283.

Ministry of Environment, Physical Planning and Public Works (MEPPPW) 2001. Air pollution in Athens: a technical report for the year 2000, MEPPPW, Athens. p. 2 (in Greek).

Nassis, G. P. and Geladas, N. D. (2002) 'Cardiac output decline in prolonged dynamic exercise is affected by the exercise mode', Pflugers Archive-European Journal of Physiology, 445, 398-404.

Nielsen, B., Hales, J. R. S., Strange, S., Christensen, N. J., Warberg, J. and Saltin, B. (1993) 'Human circulatory and thermoregulatory adaptations with heat acclimation and exercise in hot, dry environment', Journal of Physiology, 460, 467-485.

Pierson, W. E., Covert, D. S., Koenig, J. Q., Namekata, T. and Kim, Y. S. (1986) 'Implications of air pollution effects on athletic performance', Medicine and Science in Sports and Exercise, 18, 322-327.

Raven, P. B., Drinkwater, B. L., Ruhling, R. O., Bolduan, N. W., Tauchi, S., Gliner, J. A. and Horvath, S. M. (1974) 'Effect of carbon monoxide and peroxyacetyl-nitrate on man's maximal aerobic capacity', Journal of Applied Physiology, 36, 288-293.

Raven, P. B. 1987. Air pollution and exercise: physiological effects, in: Exercise, benefits, limits and adaptations, Macleod, D., Maughan, R., Nimmo, M., Reilly, T. and Williams, C. (Eds), E. and F. N. Spon, London. p. 324 345 .

Schelegle, E. S. and Adams, W. C. (1986) 'Reduced exercise time in competitive simulations consequent to low level ozone exposure', Medicine and Science in Sports and Exercise, 18, 408-414.

Tziortzis, S., Geladas, N. and Paradisis, G. (1992) 'Polluted atmosphere and training in Olympic Athletics Center of Athens', Sport Science-Theory and Practice, 7, 155167.

Wenger, C. B. 1988. Human heat acclimation, in: Human performance Physiology and environmental medicine at terestrial extremes, Pandolf, K. B., Sawka M. N., and Gonzalez, R. R. (Eds), Benchmark, Indianapolis. p. 153197.

World Health Organization 2000. Guidelines for air quality, WHO, Geneva. p. 32-40. 